\title{
Writing the Home: Charles Reis Felix's Autobiography and its Negotiation of Domestic Place and Space
}

\author{
Carmen Ramos Villar
}

University of Sheffield

\begin{abstract}
This essay explores how Charles Reis Felix's autobiography, Through a Portagee Gate (2004), examines everyday practices within the Portuguese American domestic space. The analysis also explores the interaction of the domestic setting with elements outside of this space. In so doing, the essay examines how the description of the domestic space in Felix's autobiography uncovers the unconscious construction, and negotiation, of place. Within this game of negotiating place, space, culture and identity, the essay explores how the domestic space in Felix's autobiography represents a site where the daily interaction between the public and the private, and ultimately between societies, occurs. Exclusionary notions inherent within the ethnic discourse in the United States are highlighted by reading Felix's text through the ethnic signs (Boelhower, Immigrant Autobiography) it generates. In so doing, the essay questions the validity and implications of taking a critical approach that centres on Felix's autobiography being an ethnic text.
\end{abstract}

Keywords: home, immigrant, ethnic, practices, Portuguese American, autobiography.

Charles Reis Felix's autobiography lends itself to a myriad of analytical approaches. For example, in the preface to Charles Reis Felix's Through a Portagee Gate (2004), George Monteiro points out that this text is a biography of Joe Felix, Charles Reis Felix's father, and an autobiography of Felix himself (xii). Fagundes ("Portuguese Immigrant Experience" and "Lives Parcelled out") corroborates Monteiro's analysis by carefully examining the narrative duality in this text. 
Furthermore, Fagundes comments that we could also examine this text as a historical account of the changes in a New Bedford neighbourhood, or as "a memoir of the author, but a memoir of very selective episodes or strands of that life: glimpses of a story of growing up an American-born child of a Portuguese immigrant couple in New Bedford." ("Portuguese Immigrant Experience" 707). In this way, Felix is a member of an ethnic community who educates the reader about his culture through his own life story, and also presents the reader with an immigrant's life through the telling of his father's story. This makes Felix an ethnic autobiographer when he tells his own story and the ghost-writer of an immigrant when he tells his father's story, thereby neatly collapsing the formal distinction between ethnic and immigrant autobiography. ${ }^{1}$

Through a Portagee Gate is divided into three parts. Part 1 contains extracts of an 1893 essay by Francis A. Walker (one of the presidents of MIT), discussing the corrupting effects of immigration on United States society. These extracts are intercalated with chapters where Felix describes his early career as a teacher in California and his efforts to hide his Portuguese roots. Part 2 mainly provides a biography of Felix's father, but its chapters alternate between describing events in his father's shoe shop and describing the domestic setting of Felix's house. Part 3 provides an account of Felix's high school and university years and culminates with the death of Felix's father. This essay will focus mainly on Part 2, where Felix's depiction of the home will enable an analysis of one of the many ways in which he engages with an extra-national space created by the daily interactions between societies in the emigration setting of a Portuguese immigrant community in New England. This approach will highlight the home as a privileged space where there is an interaction between what lies outside its walls, the public, and what lies within the private space of those walls so as to examine the cultural contact between Portugal and the United States in the Portuguese American home.

The home has been seen as an embryonic community that is fixed neither in space nor in time (Douglas 288-89). The distinction between home and house involves an emotional aspect; the home could be said to constitute a discursive space (see Moore) where the memory and performance of a private and domestic space may be found in particular routines, habits, smells, and 
tastes (Douglas 287). This introduces the idea of the home as a space where one feels at ease, a neutral space, "a realm of cultural autonomy" (Morley 441), and of domestic cultures that, as Joanne Hollows comments, "are not bounded and fixed but are always interconnected with life outside the home" (1). In this way, it could even be asserted that the immigrant (and/or ethnic) home includes cultural elements of both the society of origins and the society in which they live. ${ }^{2}$ This produces an image of the home as a private space that allows the immigrant or ethnic, on the one hand, to be in contact with his or her culture of origin and, on the other hand, to assimilate, incorporate, or select the cultural practices within the everyday culture of the society in which they live. In his depiction of the home, Felix presents a dual space that is both familiar to the reader, and which the reader also imagines the ethnic self to inhabit. As this essay will show, the duality in this space comes from it being simultaneously universal and particular. It is also a space in which Felix is able to make use of what Boelhower calls the ethnic writer's "interpretive gaze [...] whose strategy of seeing is determined by the very ethno-symbolic space of the possible world he inhabits" (Through a Glass Darkly 86-7).

In the many descriptions of rituals and habits within the Felix household, we not only see how Felix's family is remembered, but we also observe how this family incorporated values and cultural practices from Portugal into their everyday life in the United States. For instance, Felix describes how his father used to send him to buy jelly beans on Thursday so that the family ate them together on Sunday, before lunch, as they gathered round the table to play games. Felix's memory of eating these jelly beans is described as follows:

We took two at a time. We each took turns. I liked the black ones the best, the licorice ones. So did my sister. But we never chose a black one. We left them for my father because we knew he really loved them and since it was his money that had bought the treat, it didn't seem right that we should pick them (225).

In this description, an unspoken code of behaviour based on respect for the father, as provider and as head of the family, can be seen. This respect for 
the father as a provider perhaps reflects the time period in which this section of the narrative was set, in the 1930s, giving this section of the narrative a universal flavour. However, if the examination of this episode were to look for Portuguese ethnic signs, it could be argued that, unconsciously, the author is also reproducing particular Portuguese cultural practices; the respect for figures of authority reflects Portuguese strict codes of social conduct and behaviour. It is no coincidence that the Portuguese Estado Novo, which emerged after Felix's parents emigrated to the United States and which was strongly influenced by Catholic notions around the family, would go on to promote the image of the nation as one big family led by the benevolent father figure of Salazar (head of state from 1932-1968). ${ }^{3}$ However, as it will be argued later, looking for Portuguese ethnic signs means only engaging with the text in a limited way that particularises and even stereotypes this experience by producing generalising statements and observations about Portuguese culture that might not have been intended by the author, and which might also be incorrect.

In Felix's text, the organisation and hierarchy of the family can be observed through descriptions of how the family spent time together. For instance, the set routine for the Sunday roast preparations is shown to the reader. On Friday the mother would buy a chicken from a farm owned by a Portuguese family, bring it home, and put it in the cellar; on Saturday, she would ask Charles Felix to help her kill and prepare it for roasting on the following day. The bickering between Felix's parents before anyone could eat the roast chicken is also described as a repeated domestic ritual. After eating, the father would then tell stories to his family around the dinner table. As can be seen from the quote below, repetition and routine results in comfort, reassurance, and a desirable stability:

Child psychologists tell us that the terrifying fear of parental abandonment lurks in the hidden recesses of every child's mind. Perhaps my parents' greatest gift to me was to provide me with a sense of security so powerful that the possibility of parental abandonment never crossed my mind. They gave me the certainty that they would always be there. They were the fixed, unchanging points in my universe. They were like the sun and the moon. 
They gave me stability, order, and a profound sense of routine as a way of life. There were no sudden exciting surprises. I found this way of life calming, not boring. I was an imperfect American.

For example, we always had the same thing for Sunday dinner-roast chicken with roast potatoes (177).

In this extract, Felix describes himself as an "imperfect American", a description based on the American self being perceived as being in constant movement, and on non-repetition. However, repetition is, in fact, one of the ways in which Felix creates, both structurally and thematically, a mosaic effect in his narrative. Structurally, as was noted earlier, Felix's text is divided into three parts. These parts are composed of chapters whose content references back to themes or ideas in earlier chapters, even if they are placed in different sections of the text. These repetitions achieve, in Fagundes' words, an "unrushed weaving of integrated tales that tell an overall powerful story" ("Portuguese Immigrant Experience" 708). Thematically, Felix’s text includes many instances where the repetition of similar scenes and motifs in the narrative can be seen. ${ }^{4}$ These repetitions produce a narrative break through which a different point of view on a particular issue is introduced, thus revisiting and reordering the interpretation of that issue anew. This becomes a narrative ritual where the repetition of praise for the quality of the food consumed reminds the reader of similar scenes in previous chapters. This has the effect of both emphasising the particularity of the Felix home and, at the same time, the universal quality of Felix's depiction of family life and its particular rituals and habits in the home space. By way of example, Felix's father is shown to appreciate his food with comments such as " $[\mathrm{t}]$ hese string beans melt in your mouth! With certainty they did not come from the store. They came from your garden!" (263). A reader familiar with Portuguese language can see how Felix has used linguistic calque whenever he is reproducing his parents' speech. Felix might have intended the use of non-standard English in his narrative, as well as the description of the enjoyment of Portuguese food, as a way to build up the Portuguese atmosphere of his home life and, thus, highlighting it as a specific ethnic space. However, the use of non-standard English causes a sense of 
estrangement for the reader who is not familiar with Portuguese culture. ${ }^{5}$ This estrangement could be interpreted as a further way in which the autobiography shows the intersection and presence of Portuguese cultural signs within the private space of the immigrant home in the United States. It could also be a way of highighting a family ritual or habit before eating which may be considered ethnic, if Felix's family is read as being a representative example of their immigrant community in the United States. This reading, as will be explored later, is problematic for a number of reasons.

Food as an unconscious and embodied reminder of nationhood is, according to Palmer, important for "what it represents within the society in which it is bought, prepared and eaten." (188) The pleasure of eating dried salted octopus that had come from Portugal, which is described by Felix as as "a Portuguese delicacy" (226), could also be read as a communal act which brings comfort; it is a taste of Portugal away from Portugal, in the private realm of a Portuguese immigrant's home in the United States. It is a way of reinforcing the memory and the performance of origins. It also reiterates the importance given to the act of eating, and to routines that are carried out as a family. As Boelhower explains, the description of the consumption of ethnic food in ethnic autobiographies acts as an apprenticeship that "entails a representative symbolic perspective of food, a common store of ethnic wisdom, maxims and folklore, not to speak of a shared cultural passion" (Through a Glass Darkly 115). Boelhower argues that the culture of origins exists only in memory, and in the re-enactment of that memory. He interprets the presence of the feast in the narrative as a performance (or ritual) of ethnic memory, with a particular time frame and a particular way in which the world is viewed by its participants (Immigrant Autobiography 203). It could be argued, however, that the culture of origins is present in a more dynamic way, bringing with it many meanings and interpretations that are dependent on when and how something is remembered in the present. This more dynamic interpretation allows the reader to engage in what Fred L. Gardarphé describes as "literary ethnography" (19) in order to

develop a way of reading literature $[\ldots]$ that is not so much reading such works as products of ethnic writers as reading them for the ethnic signs 
produced by their American writers [... The critic of multicultural literature needs to know how to read the signs generated by all the cultures that have shaped the author (15).

Reading Felix's text according to the ethnic signs it generates enables the reader to see that the memory of eating Portuguese-style food does not have the same meaning for him as it does for his parents, nor does it conjure up the same feelings. To his parents, as first generation immigrants, it is the taste of "home-away-from-home." It is one of the many ways in which Felix's parents bring the culture of their immigrant origins into the daily life of the society to which they have emigrated. Eating Portuguese food conjures up further images, and memories. This idea is echoed by Alba's comments about how "[f] ood or language can provide the basis for celebrating and renewing the solidarity of common ethnic background [...] based on a mutual appreciation of ethnic heritage" (85). It is also expressed as follows by Meneses: "Like all culturally defined material substances used in the creation and maintenance of social relationships, food serves both to solidify group membership and to set groups apart" (24). Depending on how food and the rituals of consumption are viewed, it can be a universalising aspect which also particularises a certain experience implicit within the act of eating. For Felix's parents, food reinforces the idea of the home as a safe haven in which they can practice cultural autonomy. In other words, the capacity of reproducing their own culture through a performative memory gives them a sense of ontological, cultural and even territorial continuity. For Felix, on the other hand, the description of eating Portuguese food brings forth the memory of the taste of childhood in the United States-the specific childhood of an offspring who has Portuguese parents. As we saw in the extract above, eating Portuguese food is also comforting for Felix due to its repetition and predictability, becoming an act where the culture of his family's origins was present in everyday insignificant details. Although the effect of the meaning behind the act is different for the first and second generation, it could still be described as having both a transnational and transcultural aspect in the ways in which each generation reproduces and regards this act; the transnational aspect comes from the act of eating Portuguese food on 
United States soil, whilst the transcultural aspect is brought about by the meaning behind the food that is consumed, the feelings conjured by eating this food, and the cultural codes evoked, or reaffirmed, within the act itself. This recalls Douglas' comments that "a home is not only a space, it also has some structure in time $[\ldots]$ it is for people who are living in that time and space" (289). This observation also echoes Gardarphés description of how immigrant autobiographers combine memory and imagination to look beyond nostalgia and "fashion a usable past in which [...] [to] locate the cultural elements needed to create integral selves" $(121){ }^{6}$

Felix's description of himself as an imperfect American shows a tension provoked by inhabiting two cultures at once, and of having to navigate between them. This makes Felix engage in a constant comparison and evaluation of the difference between cultures. We read, for instance, how embarrassing it was for Felix to see his mother walk down the street with a live chicken in her bag:

I would pray the chicken wouldn't squawk as she went by. But Senhora Fragoza gave the whole thing away. She was from a part of Portugal where the women carried things on their heads and here she came with farm produce in a basket on top of her head. Nobody on our street carried things on their head except her so I was mortified when she came by. It was like something out of Africa. [...] [E]ven though she wasn't my mother, my mother was with her. But the guys were good about it. None of them made cracks about live chickens or carrying stuff on top of your head (178).

Felix goes on to recall how his mother justified buying a live chicken from a farm because it guaranteed its freshness and taste. Her comment on the taste is an interesting cultural juxtaposition: "Maybe you have no taste but your father and me, we can taste when it's fresh. We know!" (179). Charles Felix's request for her to behave in a more American way by buying a (dead) chicken from a supermarket, and the rebuke it receives from his mother, could be interpreted as a way in which Felix shows his family's maintenance of Portuguese cultural pratices within the private space of the home. However, it could also be asserted that his mother has implied that he is an imperfect Portuguese 
precisely because he would question something that readers might interpret as a Portuguese custom. This highlights a further duality of interpretation as regards the reader. Readers familiar with Portuguese customs will recognise the home-reared chicken for Sunday lunch as something that is common in rural areas of Portugal. This could be seen as a universal cultural code within Portuguese society. In Felix's text, it can also be seen as a particular code of Portuguese ethnicity, embedded within a more universal attitude to food within the American mainstream. Felix's constant comparison and evaluation of the disparities between cultures may be seen as his way of navigating his feeling of being an imperfect cultural self in order to make sense, and find a place, between cultures. His description of the different attitudes to courting rituals between the Portuguese and the Americans may be read in this vein; whilst relationships between Americans are seen as casual, a relationship with a Portuguese woman follows strict codes of behaviour and the intention to marry, and Felix's evaluation is that he much prefers the American model of dating (273-75). However, Felix comes to the conclusion that he would never be able to have the same experience because "it wouldn't be the same. [...] I was too self-conscious. I was Portuguese" (275). It must be remembered, however, that Felix bases his perception of a (perfect) American on artificial images of the American way of life derived from, for example, the aspirational Coca Cola billboard advertisements around his neighbourhood or, more pertinently, from what he hears at home. For instance, and returning to the importance assigned to food, as can be seen in the quote below Felix's father praises eating soup by juxtaposing it with a less desirable (and imagined) American alternative:

Americans don't eat enough soup. That's why they are always getting ulcers. It comes from eating dry food. What is the main dish in America-meat with potatoes, isn't it so? No liquids, see? Such a diet is bad for the stomach; it's too dry. [...] I know I wouldn't like to eat like that, everything so dry. I like soups. There is nothing better for your health than a little soup (203).

By giving it the nondescript name of soup, Felix is perhaps trying not to exclude a non-Portuguese reader at the same time as he exalts the merits of 
eating in a Portuguese way. In another instance, Felix description of his father's breakfast as "sopinhas de leite (milk soup), chunks of Portuguese bread floating in a bowl of warm milk" (255) provides a cultural clue to the reader who is not familiar with Portuguese customs. Fagundes's comments about the use of literal translation are pertinent here; he describes their use by Felix as a way in which the meaning reaches "the reader with all the force of the immigrant's own voice translated into English, but not lost in the translation" ("Lives Parcelled Out" 160). It could also be one of the ways in which Felix unwittingly invites the reader to understand the ethnic sign with which s/he is being presented, and to engage in the same cultural juxtaposition. Understanding the ethnic sign present in, for example, the praise his father gives to eating soup means understanding the judgement that Felix's father makes on the culture into which he has emigrated. However, Felix could also be alluding to how problematic it is to universalise a particular experience. In other words, Felix could be highlighting the difficulty and the contraditions inherent in identifying the boundaries of signification of the ethnic self when cultural juxtaposition is embarked upon.

Felix's description of an American family that moved into his neighbourhood enables him to engage in a cultural juxtaposition. The American mother, in particular, comes under strong scrutiny by Felix's mother. The comments Felix's mother makes about the American mother range from her behaviour to her conduct in public and how she runs her home. For instance, she is censured for having exposed herself when sunbathing in her garden, not looking after her child properly, going to bars on her own, and coming home from them in a drunken state. Moreover, the American woman's decision to take on a maid is also frowned upon by Felix's mother. Significantly, the reaction Felix's mother has to this American family allows Felix to explore the difference in the expectations for women between the two cultures. Felix explains that his "mother was rather conservative [...]. She never let my sister take out the swill at night for fear that an admirer might be lurking on the dark stairs [...] [fearing that] she would walk in the house pregnant" (284). It is interesting to note that Felix describes how his sister tried to justify the American woman's behaviour only to be chastised by her mother. The reaction his mother has towards the American woman's behaviour could be interpreted as her response to a perceived threat to the moral code that 
Felix's mother tried to instil in her children, and in particular in her daughters. In this respect, it could be said that Felix's mother is trying to transmit a moral code, fulfilling a similar role to that which was expected of women in Portugal (see Flunser Pimentel). This reading would give Felix's mother an important role within the narrative and, therefore, contradict Fagundes' analysis of Felix's mother as "often reduced to the level of a foil character for the father" "'Portuguese Immigrant Experience” 707). Far from being a foil character, Felix's mother could be seen as demonstrating her wish to educate her children to behave in a culturally appropriate (and even a Portuguese) way, thus making her a cultural and moral guardian for the household. Moreover, the examination of Portuguese codes of conduct and morality by Felix can also be seen as yet another way in which the two societies intersect daily, adding yet another transnational, and transcultural, layer to his narrative. In a sense, Felix's mother appears as a transnational guardian through the education, which is based on Portuguese codes of conduct, that she imparts to her children. Felix, on the other hand, could be perceived as a transcultural messenger who bridges the cultural divide with his text, enabling the reader to understand the customs and the moral code that informed certain behaviours and opinions in his childhood home.

The reaction Felix's mother has to this American family also acts as an example for the way in which judgements on other cultures are made; Felix's knowledge of the American family is based on gossip or indirect information, such as Senhor Fragoza's (the American family's landlord) comments regarding the state that the house was left in after the American family departed:

Sonny [the family's son] had pounded nails in the floor. Some had not gone in straight and were bent over, crooked. What looked like the remains of food was smeared over the wallpaper at Sonny's level. There were gouges in the plaster walls. The door to the bedroom hung by one hinge. The doorknob to the bathroom was missing. The tub in the bathroom was beyond dirty, so encrusted that it was hard to believe anyone dared use it.

"The Americans," Senhor Fragoza said, "they have no respect for anything" (289). 
The judgement made here on the American family could be seen to violate their right to consider the home as a space where one can speak freely and exercise cultural autonomy, as discussed at the beginning of this essay. The American family is being judged on, and by, how they lived inside the house. The universal and the particular thus intersect here by providing a narrative space in which the specific ethnic voice makes an observation about the respect for the home that can also be described as a universal attitude. However, the final line spoken by Senhor Fragoza constitutes a cultural juxtaposition that recalls lines from the essay by Francis A. Walker quoted by Felix in Part 1 of this autobiography. The American family enables Felix to show that Walker's comments also apply to non-immigrants; the American family is shown as dirty, untrustworthy and lacking in morals, and, in a way, as living (and behaving) like animals. In providing a negative image of the Americans that borders on stereotype, based on how they live as described by a first-hand source, Felix's description acts as a metaphorical mirror that reverses what is universal and what is particular when comments about culture are made. This mirror's reflected image also reverses the criticism aimed by Walker at immigrants in the United States. Felix thus deconstructs Walker's discourse and, in so doing, shows that the stereotype of the Portuguese community in particular is an unjust and inaccurate misreading of the culture and values of this immigrant group. However, Felix also makes use of this stereotype and, sometimes, cultivates and confirms certain perceptions of the Portuguese. As will be argued later, this has the effect of questioning essentialist notions of ethnic identity by showing that it is a far more complex and contradictory construction that is based on a number of factors such as class, culture, perception and construction of race, etc.

The home, as mentioned earlier, could be seen as a neutral space composed of many places and discourses that link and intersect (Morley 441). It is also a space from which, as Hareven points out, "the world is viewed" (260). This reading of the home could also be applied to Boelhower's comment that among the many roles of the ethnic autobiographer is that of uncovering "the coded space he is in [so as to provide] the didactic juxtaposition of two worlds" (Immigrant Autobiography 38). One of the ways in which Felix does this is 
through the reproduction of the stories that Joe Felix (his father) used to tell his family at home. ${ }^{7}$ Through these, we see an intimate portrait of a Portuguese American home, and how this domestic space is interconnected with the space outside the home in more ways than just the food they eat. The stories allow Joe Felix to transmit and reinforce a moral code that inadvertently shows a blueprint of Portuguese values, customs, particularities and acceptable behaviour. The stories can be described as parables with a moral attached to them, bringing to mind Reinaldo Silva's observation that "Joe Felix delights in helping needy widows and their underage children, acting, in essence, as a good Samaritan even if he-unlike most Portuguese immigrants of his time-did not attend the local church regularly. Instead of listening to the gospel, he put it into practice." (Portuguese American Literature 75) This comment recalls a brief remark by Felix which highlights that the family did not go to church on Sunday, as would be expected, as Silva points out, from a Portuguese immigrant Catholic family. Not going to church might be one of the reasons why Felix identifies his father as being an imperfect Portuguese, something that is particularly evident when Felix compares his father to his maternal grandfather. While Joe Felix is shown to be a hard-working and loving father, his grandfather is described as both a Portuguese patriarch whose children live in fear of him, and as a bon viveur. In comparing both men, Felix highlights how Joe Felix leads by example rather than hide behind cultural practices, like Felix's grandfather, practices that are outward-facing, or marks of status within the Portuguese immigrant community.

Through his stories, Joe Felix could be said to bring the outside world within the domestic space so as to complement the moral code that the mother, as the moral guardian of the home, imparts to the children. The reader is being educated into, and about, a culture so that, to extend Hareven's earlier comment, the home also becomes the place in which the reader views, or learns about a particular culture. Joe Felix fulfils a similar function to the Sicilian storytellers that Boelhower examines in Mangione's autobiography; through the stories, Joe Felix also creates a cultural space from which to transmit his cultural patrimony, and in which the "values transmitted are part of the transmission of values" (Immigrant Autobiography 205). In other words, like the Sicilian 
immigrants that Boelhower examines, Joe Felix is a mouthpiece through which we learn about how and why the immigrant sees the world around him the way he does. In so doing, Joe Felix becomes a bridge through which transcultural understanding is possible; and the author lends his father visibility beyond just allowing him to have a voice in the text that enables him, as Fagundes notes, to become the centre of the action and the narration ("Lives Parcelled Out" 156). Joe Felix is also the instrument through which the alternative ethnic perspective is given, making him a cultural informant that allows the reader to understand Portuguese culture as he understands it, thus completing the transmission of values commented on above. This interpretation expands upon the description made by Fagundes of Felix's autobiography being "a teacher's story in which the teacher alternates between his role as learner and as teacher" ("Lives Parcelled Out" 154). The stories that Felix reproduces act as a cultural map that navigates ethnic signs that would otherwise not be apparent to the reader. These ethnic signs are both Portuguese and American, and they show not only the immigrant's way of perceiving his own reality, but also the other side of the coin: how that immigrant views others. The fact that these stories are told around the dinner table by Joe Felix brings another dimension to the surveillance role that Wright (218) assigns to the domestic space. Through the stories, Felix shows how the immigrant filters, understands, and assimilates concepts between cultures. The stories also demonstrate that cultural misunderstanding and mistrust are mutual and, like Walker and the Californian characters that Felix describes in Part 1, the same criticism could be put to, say, the attitudes that Felix's father expresses about certain immigrant groups (not to mention Americans themselves) in his stories. The stories Joe Felix tells are mainly about the local immigrant community and, in a sense, they hold this community up for examination. For instance, Felix's sister interrupts a story to ask Joe Felix about which nationalities make the best customers after her father describes how a Polish man had been bankrupted by his Polish customer friends. She receives the following answer:

I don't know who the best are, but I can tell you this, I know who the worst are. The worst are the Portuguese. When I see a Portuguese on my top step, 
ready to come in, I give a shudder. They think that because you are a countryman of theirs, you should do the work free. No matter what the price is, they always want it lowered. [...] It is always that way. You see, when people are of the same language as you, they want special treatment. They think that should give them the right to sponge off you. I would rather see any other race enter my shop than the Portuguese. When a Portuguese enters my shop and I hear this greeting, Oh Compadre! I brace myself (189).

Felix does not want to highlight that the Portuguese are untrustworthy, or that they take advantage of their fellow Portuguese immigrants. The observation was made on the back of a story that illustrated how someone from another immigrant group had gone out of business because of the preferential treatment he gave to his fellow countrymen. The story serves to answer George Monteiro's rhetorical question in the preface to Felix's autobiography: "what is one to make of the author's perhaps too-sharp eye for the embarrassing detail, his predilection for casting incidents and character ironically, his sometimes ham-fisted satire at the expense of the ethnics (including the Portuguese) who appear in his narrative?" (xiii). It could be proposed that Felix's constant cultural juxtaposition seeks to provide a bridge of mutual understanding between cultures. Joe Felix's answer, thus, may be interpreted as a way in which he is asking his listeners (his children and, by extension, his readers) to understand that kindness and preferential treatment should be shown to those who need it. In other words, the stories enable Felix to provide even-handed criticism and to teach the reader to understand and learn about his immigrant family and their values. By showing the flaws behind certain attitudes, Charles Felix is also able to highlight that no culture is superior.

Feldman-Bianco's observation of the Portuguese immigrant home as a transnational space where layers of time (past historical discourses, or the organisation of the home, for example) are present (64) can also be extended to our analysis of the way Felix depicts his childhood home. The stories in Felix's narrative, as this essay argued, act as a filter which enables a verbalisation and evaluation of cultures through the retelling of experiences outside the domestic space. In so doing, Felix shows how the immigrant seeks to bring order and 
make sense of the immigrant experience and of the society in which s/he lives, making the home an empowering discursive space in which meaning is created. The home might seem a turbulent space of negotiation that, as Petridou lucidly explains, "acquires its meaning through practice; and as such, it forms part of the everyday process of the creation of the self" (88). The inclusion of descriptions of Portuguese cultural practices in the home, the food consumed, the conversations that took place in private, the letters that arrived from Portugal, or the clothes worn, are some of the ways in which Felix shows how his childhood home was dynamically connected to a space beyond the physical home of the United States. However, Felix also describes how he consciously tried to make his Portuguese background invisible outside the domestic space. This provides an interesting reversal of what Alba, recalling Gan's argument, characterises as symbolic ethnicity when describing a person who wishes to be seen as a member of an ethnic group and, thus, makes "a conscious attempt to 'feel ethnic', to the exclusion of 'being ethnic"' (76). In Felix's case, we read how he made conscious attempts not to be labelled, or to feel, ethnic. To paraphrase Canti, we see how Felix engages in the conspicuous denial of ethnic signs so as to be accepted into mainstream culture (10-11). Paradoxically, the autobiographical text is a way in which Felix could be said to make his Portuguese ethnicity visible. This paradox will now be examined in more detail.

Not paying attention to the description of daily interactions between cultures in Felix's autobiography, such as what kind of food is cooked and how it is enjoyed, means overlooking or misreading the ethnic signs, to use Gardarphés expression once more, even if these signs are unconsciously placed in the narrative by Felix. Felix's text has been analysed above using this multicultural framework of the politics of ethnic visibility in the United States. Fagundes also points to the fact that Felix's text can be read as the story "of the ethnic who earlier in life had what amounted to an internal (im)migrant experience" ("Lives Parcelled Out" 152). Silva describes Felix's autobiography as capturing "the mindset, ways and motives of thousands and thousands of Portuguese immigrants who yearned to start a new life in America" (Portuguese American Literature 79). Silva places Felix's autobiography among works of other Portuguese American writers who "succeed in retrieving their ancestors' roots so as 
to learn more about where they came from" ("Representations" 205). Finally, Silva identifies the works of Portuguese American writers, Felix included, by how they address the misrepresentation of the Portuguese as an ethnic minority within the United States, arguing that these works set the record straight about Portuguese immigrant culture, and that they give depth to the surface glimpses of Portuguese cultural customs ("Representations" 153, 157). Moreover, both Monteiro and Fagundes ("Lives Parcelled Out") point out that Felix wrote his autobiography on an impulse to correct Francis Walker's comments (which Felix quotes in the text), and thereby show a true picture of the Portuguese community in the United States. ${ }^{8}$

Looking at Felix's autobiography through the Portuguese ethnic lens, however, is one of the many ways in which the ethnic label "Portuguese" is used simplistically within the United States. Its use goes beyond that of describing people who emigrated from mainland Portugal to include people from the former Portuguese colonies, with very different experiences and perceptions of the world. As Moniz comments, the reductive use of the term "Portuguese" collapses the nuances of the identities of the Lusophone worlds present in the Portuguese American community. ${ }^{9}$ Placing Felix under this label disregards the methodical deconstruction of labels and stereotypes, both of the Portuguese American and of the wider American community, that Felix carries out in his autobiography, where he is at pains to show us that essentialisms need to be resisted, questioned, and corrected. ${ }^{10}$ In so doing, Felix's text becomes a marginal ethnic contribution to the multicultural debate on the belief that, as Boelhower points out,

\footnotetext{
the identity crisis of Americans can only be handled as ethnic discourse, since everyone in America is willy-nilly an ethnic subject. The US is a combination of many voices. The question of "what is an American?" is also an ethnic question for obvious genealogical reasons. (Through a Glass Darkly 33)
}

Taken to its extreme, and as Boelhower points out (Through a Glass Darkly 34-6), autobiographies such as Felix's are reduced to entries into a "list" which are ranked and categorised as either mainstream or ethnic, thereby perpetuating the debate about where to draw the line between the distinction of 
universal and particular, ethnic and American. This is a debate that is examined in a sociological study on the Portuguese immigrant community in New England carried out by Clyde Barrow, where he observes that first generation immigrants "are non-American by their own definition of what it means to be American [...] [I]t is only their children-born in the United States-who are perceived as 'truly' and 'completely' American, even within the PortugueseAmerican community" (302). However, Felix, who was born in the United States, in describing himself as an imperfect American, is voicing how even the second generation does not feel completely American. Could the complex nature of Felix's text stem from the ethnic self that writes? This assertion would echo Boelhower's analysis of the ethnic autobiographer as reading, or interpreting reality in a different way, and as "a subject who at any given moment can reverse its position and float meanings from one world to another" (Through a Glass Darkly 138). It might explain the reasons behind the paradoxical nature of the text; Felix makes his Portuguese ethnicity visible, but only many years after the events that are narrated in the text. Could he be using his ethnicity strategically? Felix makes the following comment in an interview:

I do not "slant" my books to either a Portuguese audience or a non-Portuguese audience. The book itself dictates which way it's going to go.

But here is the vexing part for me. Portuguese-American scholars have kept me alive. The bulk of my work would not have been published without them. But I feel a certain unease. For example, I have written a novel [...] about three teachers at a suburban elementary school in California. Now the word "Portuguese" does not appear in the novel, although one of the teachers is named Seraphim. My concern is this: should the novel ever be published, will the Portuguese-American community of scholars totally disregard it because it lacks a clearly defined Portuguese presence? So being a Portuguese-American writer is a double-edged sword. It can help, and it can hurt (“I Write Nonfiction Fiction” 224).

Could critics be seeing Felix's autobiography as a Portuguese American, and therefore ethnic text solely because it has been published in the 
"Portuguese in the Americas Series" of a Portuguese American publishing house? The answer is probably no, due to how Felix depicts the Portuguese American experience within the text. In highlighting how Felix gives visibility to his ethnic group, we disregard the warning against falling into the essentialist descriptions that Felix gives the reader in the text. As Felix illustrates, concepts such as race, ethnicity, culture and cultural practices are very complex and contradictory to define.

As has been argued, the home is an empowering space where cultures, practices, habits and behaviours are examined to arrive at some kind of transnational and transcultural understanding. However, it is incredibly difficult, perhaps even impossible, to define what is particular and what is universal within this space. Taking the earlier example of the American family that moved into his neighbourhood, Felix limits himself to narrating the episode as an observer. In so doing, he comments how his sister tried to explain the American woman's behaviour only to be chastised by her mother, thus showing the reader that he neither agrees nor disagrees with either his sister or his mother. Like his father, Felix is a cultural informant who seeks for the reader to understand where the complexities and the contradictions emerge when seeking to understand experiences that are translated into practices in a never-ending process of estrangement, adaptation, and maybe adoption or rejection. Felix shows the reader that there are no pure cultures, and there are no pure ethnicities, thus rejecting essentialist definitions. If this is the case, is it not time for critics to move beyond the analytical binary of the ethnic/mainstream label within autobiographical literature in the United States? Moving away from these analytical boundaries will enable critics to look at the autobiographical text for its own merit, rather than for the uses to which it can be put. 


\section{Notes}

1 This distinction between ethnic and immigrant autobiography is to differentiate between an autobiography that has been written by a member of an ethnic community, who might be part of the second, or third generation, and an autobiography written by a first-generation immigrant.

2 The term "host society" has not been used deliberately so as to reflect the ambivalent relationship that the immigrant and his/her subsequent generations have with both societies. For instance, the second-generation immigrant does not consider his or her parents' "host society" as such, nor do they consider the society of their parents' origins as their society of origins. This forms part of the problematic conception of the "public home" in immigrant autobiography (Ramos Villar). The distinction between an immigrant and/or ethnic home is also tied up with this ambivalence; although there is a degree of crossover between the two terms, we could describe Joe Felix as representative of the "immigrant" in Felix's text, and Charles Reis Felix as representing the "ethnic." In other words, the descriptors assigned to each man arise from a legal and an emotional perspective respectively. Charles Reis Felix could not be described as an immigrant, but he could be described as being the son of an immigrant, and therefore having a Portuguese ethnic background. Distinctions such as these are problematic because of their ambivalent nature.

3 This image of the nation led by a patriarch who provided for his family also promoted specific roles for each member of the family. In her study about women under the Estado Novo, Pimentel provides an excellent point of departure for those interested in a more detailed examination of this aspect. In the immigrant context, Lamphere et al. make a similar observation regarding the respect for parental authority and to the father as provider in Azorean immigrant families, an observation that could also apply to immigrant families from the Portuguese mainland (367).

4 Incidentally, Reinaldo Silva (Portuguese American Literature 77) also comments that Felix uses certain scenes, such as the Sunday roast scene, in his other novels. This could be viewed as an intertextual repetition.

5 The way in which Felix reproduces his father's speech, and the code-switching present in this narrative, deserves a more sustained study than can be given here for questions of space. Readers are directed to Fagundes ("Lives Parcelled Out"), who has described the way Felix reproduces his father's speech as a narrative device which lends the text an oral quality, and which endows Felix's father with his own voice in the narrative (157-61).

6 Although Gardarphé is referring to the way in which the third-generation immigrant uses memory, nostalgia and imagination as a creative process, the argument in this present essay shows that his observations can also apply to the first and second generation. Readers interested in the use of nostalgia as a creative process, and its interplay and relationship with memory within Portuguese American autobiographies, are directed to Ramos Villar.

7 Fagundes' examination of the stories is fleshed out further in "Lives Parcelled Out". Moreover, in "Portuguese Immigrant Experience," Fagundes also notes that the ability to tell a good story is something that Felix inherits from his father, producing an interesting narrative blur between Felix's reproduction of his father's storytelling and Felix's telling the story of his father. Fagundes' comment is worth noting in full:

[I]t is no exaggeration to say that Through a Portagee Gate is a story made up of stories. The gate of its title being construable as a metaphor for a threshold that the reader passes through on his or her way to a world of storytellers and story- 
telling. It is as a storyteller, perhaps as much as any other of his many qualities and virtues as a person, that Joe Felix is remembered. It is largely as a storyteller that Charles Reis Felix pays homage to his father. And it is as a storyteller that Charles, as a writer, shows himself to be his father's son, the literary re-creator and imitator of his father's oral storytelling capabilities. (707-708)

8 Regarding this, Fagundes makes the following observation: "Behind the biographical/ embedded autobiographical component of Through a Portagee Gate there are at least two obvious intentions. One of them is to counter the xenophobic attitudes about immigrants, like the one expressed by Francis A. Walker [...] Walker's xenophobia is echoed in the stereotypical bigotry of several of the characters whom Charles encounters in his California journey. The other intention was equally significant, or perhaps even greater: not only bearing witness to the experiences of the immgrants, but also lending them voices with which to tell their stories" ("Lives Parcelled Out" 156).

9 Moniz's analysis shows how the term Portuguese American is not only quite fluid, but also subject to the historical discourses of both Portugal and the United States. To take one of Moniz's examples, he explains that, when Portugal still had African colonies, these colonies were regarded as overseas provinces and part of the Portuguese state. This meant that immigrants arriving from the Cape Verde islands, for example, entered the United States with a Portuguese passport and were "categorised" as Portuguese.

${ }^{10}$ It is also interesting that Felix makes use of these same stereotypes, sometimes even confirming them, to make his point in the text. This brings to mind Bhabha's comments on the stereotype having a notion of truth within it, and being something that can be used strategically by both the stereotyped and the stereotyping when making claims of representability that can both challenge and confirm the stereotype in question.

\section{Works cited}

Alba, Richard. Ethnic Identity: The Transformation of White America. New Haven and London: Yale University Press, 1990. Print.

Barrow, Clyde. "The Political Culture of Portuguese-Americans in Southeastern Massachusetts." Community, Culture and the Makings of Identity. Eds. Kimberly DaCosta Holton and Andrea Klimt. North Dartmouth, Massachusetts: Center for Portuguese Studies and Culture - University of Massachusetts Dartmouth, 2009. 291-315. Print.

Bhabha, Homi. "The Oher Question... Homi K Bhabha Reconsiders the Stereotype and Colonial Discourse." Screen 24.6 (1983): 18-36. Web 21 Aug. 2012. <http://screen.oxfordjournals.org/content/24/6/18.short>

Boelhower, William. Immigrant Autobiography in the United States (Four Versions of the Italian American Self). Venezia: Essedue Edizioni, 1982. Print.

—. Through a Glass Darkly: Ethnic Semiosis in American Literature. New York, Oxford: University Press, 1987. Print.

Canti, Camille. “"Pass the Identity, Please”: Culinary Passing in America." A Tavola: Food, Tradition and Community Among Italian Americans. Eds. Edvige Giunta and Samuel J. Patti. Staten Island, New York: American Italian Historical Association, 1998. 10-19. Print. 
Douglas, Mary. “The Idea of Home: a Kind of Space." Social Research Vol. 58.1 (1991): 287-307. Web. Fagundes, Francisco Cota. "Portuguese Immigrant Experience in America in Autobiography." Hispania Vol. 88.4 (2005): 701-712. Print.

" "Charles Reis Felix's “Through a Portagee Gate": Lives Parcelled Out in Stories." MELUS Vol. 32.2 (2007): 151-63. Web.

“"I Write Nonfiction Fiction”: An Interview with Charles Reis Felix." Narrating the Portuguese Diaspora: Piecing Things Together. Eds. Francisco Cota Fagundes, Irene Maria F. Blayer, Teresa F. A. Alves and Teresa Cid. New York: Peter Lang Publishing, 2011. 221-230. Print.

Feldman-Bianco, Bela. "Multiple Layers of Time and Space: The Construction of Class, Ethnicity and Nationalism." Community, Culture and the Makings of Identity. Eds. Kimberly DaCosta Holton and Andrea Klimt. North Dartmouth, Massachusetts: Center for Portuguese Studies and Culture - University of Massachusetts Dartmouth, 2009: 51-94. Print.

Felix, Charles Reis. Through a Portagee Gate. North Dartmouth, Massachusetts: Centre for Portuguese Studies and Culture - University of Massachusetts Dartmouth, 2004. Print.

Gardarphé, Fred. L. Italian Signs, American Streets: The Evolution of Italian American Narrative. Durham and London: Duke University Press, 1996. Print.

Hareven,Tamara. "The Home and the Family in Historical Perspective." Social Research Vol. 58.1: 253-285 (1991). Web.

Hollows, Joanne. Domestic Cultures. Maidenhead: Open University Press, 2008. Print.

Lamphere, Louise, Filomena Silva and John P. Sousa. "Kin Networks and Family Strategies: Working Class Portuguese Families in New England." Community, Culture and the Makings of Identity. Eds. Kimberly DaCosta Holton and Andrea Klimt. North Dartmouth, Massachusetts: Center for Portuguese Studies and Culture - University of Massachusetts Dartmouth, 2009. 357-80. Print.

Meneses, Maria Paula. "Food, Recipes and Commodities of Empires: Mozambique in the Indian Ocean Network" Oficina do CES Number 335 (2009). Web.

Moniz, Miguel. "The Shadow Minority: An Ethnohistory of Portuguese and Lusophone Racial and Ehtnic Identity in New England." Community, Culture and the Makings of Identity. Eds. Kimberly DaCosta Holton and Andrea Klimt. North Dartmouth, Massachusetts: Center for Portuguese Studies and Culture - University of Massachusetts Dartmouth, 2009. 409-430. Print.

Monteiro, George. Preface. Through a Portagee Gate. By Charles Reis Felix. North Dartmouth, Massachusetts: Center for Portuguese Studies and Culture - University of Massachusetts Dartmouth, 2004. xi-xiii. Print.

Moore, Jeanne. "Placing Home in Context." Journal of Environmental Psychology Vol. 20 (2000): 207-217. Web.

Morley, David. "Belongings: Place, Space and Identity in a Mediated World”. European Journal of Cultural Studies Vol. 4 (2001): 425-448. Web.

Palmer, Catherine. "From Theory to Practice: Experiencing the Nation in Everyday Life." Journal of Material Culture Vol. 3 (1998): 175-199. Web.

Petridou, Elia. “The Taste of Home." Home Possessions: Material Culture Behind Closed Doors. Ed. Daniel Miller. Oxford/New York: Berg Publishers, 2001. 87-104. Print. 
Pimentel, Irene Flunser. A Cada Um o Seu Lugar: A Política Feminina do Estado Novo. Porto: Círculo de Leitores e Temas e Debates, 2011. Print.

Ramos Villar, Carmen. "Janus and the Portuguese emigrant: the autobiographies of Portuguese immigrants in the United States." Luso-Brazillian Review 49.2 (2012): 232-250. Print.

Silva, Reinaldo. Representations of the Portuguese in American Literature. Dartmouth, Massachussetts: University of Massachussetts Dartomouth, 2008. Print.

_. Portuguese American Literature. Penrith: Humanities Ebooks LLP, 2009. Print. "Her Story vs His Story: Narrating the Portuguese Diaspora in the United States of America." Narrating the Portuguese Diaspora: Piecing Things Together. Eds. Francisco Cota Fagundes, Irene Maria Blayer, Teresa F. A. Alves, and Teresa Cid. New York: Peter Lang Publishers, 2011. 49-62. Print.

Wright, Gwendolyn. "Prescribing the Model Home." Social Research Vol. 58.1 (1991): 213-225. Web.

\author{
Carmen Ramos Villar is a Senior Lecturer in \\ Hispanic Studies at the University of Sheffield \\ (UK). Her research interests lie in works written \\ by Portuguese emigrants to the US and their \\ descendants, in particular biographical and \\ autobiographical texts. Her publications include \\ The Metaphorical "Tenth Island" in Azorean \\ Literature: The Theme of Emigration in the Azorean \\ Imagination (2006).
}

